Materials Letters 149 (2015) p. 138-140

doi: 10.1016/j.matlet.2015.01.158

\title{
Compressive properties of natural fibre composites
}

Van Vuure A.W. ${ }^{* 1}$, Baets J. ${ }^{1}$, Wouters K. ${ }^{1}$, Hendrickx K. ${ }^{1}$

${ }^{1} \mathrm{KU}$ Leuven, Department of Materials Engineering, Kasteelpark Arenberg 44, 3001 Leuven, Belgium

*corresponding author: A.W. Van Vuure (aartwillem.vanvuure@ kuleuven.be), tel. +32 16321300

\begin{abstract}
Compressive properties of 3 different natural fiber composites are measured, based on flax, bamboo and coir fibre. It was found that bamboo performs the best of these 3 natural fibers in compression. If the compressive properties are compared to the tensile properties it can be seen that flax and bamboo composites reach between 60 and $80 \%$ of the tensile values, which is very encouraging. Coir fiber composites even perform better in compression than in tension.
\end{abstract}

\section{Keywords}

Biocomposites, compressive properties, natural fibres

\section{Introduction}

There is a growing interest in the use of natural fibres for composites. The main reasons are the ecological benefits combined with the good specific mechanical properties [1-10]. Because of the moisture sensitivity and the limited thermal resistance the real applications are still limited [11, 12]. For different applications the compressive properties are also important. However these properties are scarcely studied in literature. In [13] the compressive properties of flax fibers are studied. In this paper the compressive properties of composites with different natural fibres will be measured and compared with their tensile properties.

\section{Materials and Methods}

\section{Materials}

Three different fibres were used: flax fibers were supplied by Lineo in the form of the unidirectional Flaxtape product. The flax fibres need to be dried for $24 \mathrm{~h}$ at $60^{\circ} \mathrm{C}$.

The technical bamboo fibres which were used to produce the bamboo-epoxy-composites were of the species Guadua angustifolia, obtained from a bamboo plantation in Colombia. A wet cleaning process is applied in which the fibres are combed to remove the parenchyma cells. This also results in an aligning of the fibres. After cleaning, the fibres should be dried for $72 \mathrm{~h}$ at $60^{\circ} \mathrm{C}$ [14].

The coir fibres used to produce the coir-epoxy-composites were provided by the Can Tho University of Vietnam. These are long coir fibres which have a length between $200 \mathrm{~mm}$ and $300 \mathrm{~mm}$. These fibres were obtained from the coconut husk using mechanical extraction. The same cleaning process which was applied for the bamboo fibres, was used for the coir fibres, as well as the method of drying the fibres.

The matrix used in combination with these natural fibres consisted of epoxy resin (Epikote 828 LV) in combination with 1,2-diaminocyclohexane hardener (Dytek DCH-99). These two components are mixed in a ratio of $15.2 \mathrm{~g}$ of hardener per $100 \mathrm{~g}$ of resin. The resin should be degassed before it is used 
for the production of the composites. All of the natural fibre composites which were produced had a fibre volume fraction of $40 \%$.

\section{Methods}

The method used for the production of the unidirectional fibre composites was Vacuum Assisted Resin Infusion (VARI). A mold with a top and bottom plate was used which resulted in the production of composite plates with a thickness of 2 and $4 \mathrm{~mm}$. The infusion was performed at a temperature of $40^{\circ} \mathrm{C}$. When the impregnation was complete, the temperature was increased to $70^{\circ} \mathrm{C}$ to start the curing process for $1 \mathrm{~h}$. The post curing was done during $1 \mathrm{~h}$ at a temperature of $150^{\circ} \mathrm{C}$ in a separate furnace.

Tensile tests are performed according to ASTM 3039 with a sample size of $230 \times 12,7 \times 2 \mathrm{~mm}^{3}$ and a test span of $150 \mathrm{~mm}$. An extensometer is used. The compression tests are performed according to ASTM D3410. The sample dimensions are $135 \times 10 \times 4 \mathrm{~mm}^{3}$. The span of the compression samples is set to $15 \mathrm{~mm}$. The samples for the mechanical tests are obtained by cutting the plates with a diamond saw. End tabs were used for the flax and the bamboo composite samples, while no end tabs were used for the coir composite. During compressive testing of the coir composites, the end tabs loosened, but satisfactory results were obtained by inserting sand paper between the clamps and the samples, without using any end tabs.

The compression tests are performed using an Instron 5985 testing device in combination with strain mapping by Digital Image Correlation (Limess) at both sides of the samples. The test speed used for the compression test is $1,5 \mathrm{~mm} / \mathrm{min}$. For one sample, two moduli and strains can be determined, one for the front and one for the backside. These are averaged to determine the modulus and strain for the composite. For each of the samples, also the percentage of bending $\left(B_{y}\right)$ is determined. In agreement with the standard only the samples with a percentage bending between $-10 \%$ and $+10 \%$ are considered. $\mathrm{B}_{\mathrm{y}}$ is determined by following formula:

$$
B_{y}(\%)=\frac{\varepsilon_{1}-\varepsilon_{2}}{\varepsilon_{1}+\varepsilon_{2}} \times 100 \%
$$

where $\varepsilon_{1}$ is the frontside strain and $\varepsilon_{2}$ is the backside strain.

\section{Results and Discussion}

The overall resulting compressive stress-strain curves of the natural fibre-epoxy composites can be found in Figure 1. The graphs indicate that the flax and bamboo composites show similar stiffness behavior, and are much stiffer compared to the coir composite. The bamboo composite has the highest strength, followed by the flax composite, and the coir composite is the weakest. 
doi: 10.1016/j.matlet.2015.01.158

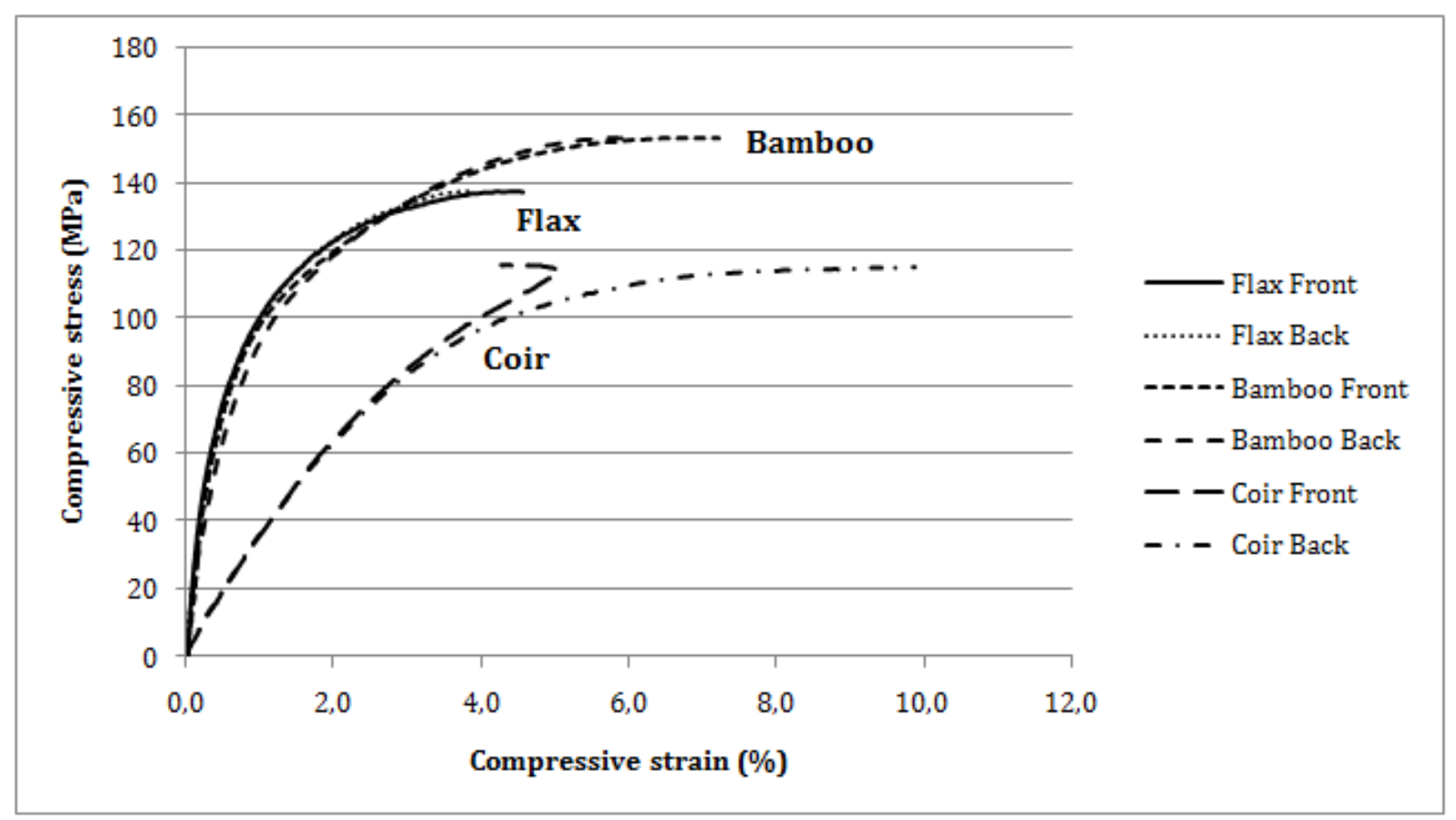

Figure 1: Typical stress-strain graphs of compression tests on the UD composites with 3 different natural fibers

The compressive properties of the natural fibre-epoxy composites with a fibre volume fraction of $40 \%$ can be found in Table 1 . The compressive strength is the maximum compressive stress which is reached during the test. The moduli of the flax and bamboo composites are similar and much larger than the modulus of the coir composite.

Table 1: Compressive properties of UD composites with different natural fibres with a fibre volume fraction of $40 \%$

\begin{tabular}{|l|c|c|}
\hline & $\begin{array}{c}\text { Compressive strength } \\
\text { (MPa) }\end{array}$ & $\begin{array}{c}\text { Compressive modulus } \\
\text { (GPa) }\end{array}$ \\
\hline Flax-epoxy & $136,9 \pm 5,5$ & $15,1 \pm 2,5$ \\
\hline Bamboo-epoxy & $149,5 \pm 8,9$ & $15,5 \pm 2,7$ \\
\hline Coir-epoxy & $116,2 \pm 5,8$ & $3,7 \pm 0,3$ \\
\hline
\end{tabular}

All of the tested flax composite samples seemed to have failed in a similar way, as well as most of the bamboo composite samples; the composite samples kink, because of the microbuckling of the technical fibers.

The coir composite samples failed much more violently and showed a different failing behavior. Their failure is caused by the brittle nature of the epoxy. The early cracks which occur in the epoxy matrix during compressive testing are pressed together so they do not propagate. Close to failure of the composite, buckling can occur which causes the matrix cracks to propagate violently through the composite and cause breakage of the fibres. There is no microbuckling appearing in the coir fibres.

A comparison can be made between the tensile and compressive properties of the different natural fibre-epoxy composites. The strength ratio and modulus ratio can be determined, which are the ratio between the compressive and tensile strength, and the ratio between the compressive and tensile modulus, respectively. The tensile properties for the flax- and bamboo-epoxy composites with a fiber volume fraction of $40 \%$ are given in Table 2 . 
Materials Letters 149 (2015) p. 138-140

doi: 10.1016/j.matlet.2015.01.158

Table 2: Comparison of tensile and compressive properties for flax and bamboo UD composites with equal fibre volume fractions of $40 \%$

\begin{tabular}{|c|c|c|c|c|}
\hline & $\begin{array}{c}\text { Flax } \\
\text { Tensile } \\
\text { properties }\end{array}$ & $\begin{array}{c}\text { Flax } \\
\text { Compressive } \\
\text { properties }\end{array}$ & $\begin{array}{c}\text { Bamboo Tensile } \\
\text { properties }\end{array}$ & $\begin{array}{l}\text { Bamboo } \\
\text { Compressive } \\
\text { properties }\end{array}$ \\
\hline $\begin{array}{c}\text { Strength } \\
\text { (MPa) }\end{array}$ & $222,9 \pm 6,1$ & $136,9 \pm 5,5$ & $254,7 \pm 18,3$ & $149,5 \pm 8,9$ \\
\hline $\begin{array}{c}\text { Modulus } \\
\text { (GPa) }\end{array}$ & $23,9 \pm 1,9$ & $15,1 \pm 2,5$ & $19,5 \pm 1,0$ & $15,5 \pm 2,7$ \\
\hline
\end{tabular}

The strength ratio for the flax composite is thus equal to $61,4 \%$, while its modulus ratio is equal to $63,1 \%$. This means that for the flax composite, about $60 \%$ of its tensile properties are maintained during compression. The strength ratio of the bamboo is equal to $58,7 \%$, but a larger modulus ratio of $82,3 \%$ is obtained. The good stiffness performance of the bamboo composite during compression might be due to the structure of the bamboo fibers, which combine an almost zero microfibrillar angle in the secondary cell wall of their elementary fibres with a $90^{\circ}$ microfibrillar angle in their outer primary cell wall [15], thus providing an outer wrap for the $0^{\circ}$ fibrils.

The comparison for coir composites is based on results of [16]. It is more difficult because these tensile samples had a fiber volume fraction of $49 \%$. The obtained tensile modulus and strength are $2,95 \mathrm{GPa}$ and $34,9 \mathrm{MPa}$ respectively. Neglecting the difference in $\mathrm{V}_{\mathrm{f}}$ this gives a modulus ratio of $125 \%$ and a strength ratio of $332 \%$ which means that the coir-epoxy composite performs very well in compression compared to the tensile behavior. In tension, cracks in the brittle epoxy propagate relatively easily through the fibers; in compression, critical early cracks are presumably closed, which delays failure of the sample.

The strength ratio for UD glass fiber composites can be determined using the data of [17]. The tensile strength is $700 \mathrm{MPa}$ and the compression strength is $570 \mathrm{MPa}$, leading to a strength ratio of $81 \%$.

\section{Conclusion}

In this paper the compressive properties of UD composites with 3 different natural fibers are compared and related to their tensile properties. It is shown that bamboo and flax perform better than coir fibers in absolute terms. If the results are compared to the corresponding tensile values it are the coir fibres which perform the best.

Compared to glass fiber composites it can be seen that the natural fibre composites perform less in compression. Also the strength ratio between compression and tensile strength is higher for glass fiber composites. However, the performance in compression for the natural fiber composites can be classified as decent with strength ratios of around $60 \%$.

\section{References}

[1] Hughes M, Carpenter J, Hill C. Deformation and fracture behaviour of flax fibre reinforced thermosetting polymer matrix composites. J Mater Sci. 2007;42:2499-511.

[2] Baley C. Analysis of the flax fibres tensile behaviour and analysis of the tensile stiffnes increase.

Comp Part A. 2002;33:943-8. 
[3] Bos HL, Van den Oever MJA, Peters O. Tensile and compressive properties of flax fibres for natural fibre reinforced composites. J Mater Sci. 2002;37:1683-92.

[4] Bourmaud A, Baley C. Rigidity analysis of polypropylene/vegetal fibre composites after recycling. Polym Degrad Stab. 2009;94:297-305.

[5] Joshi SV, Drzal LT, Mohanty AK, Arora S. Are natural fiber composites environmentally superior to glass fiber reinforced composites? Comp Part A. 2004;35:371-6.

[6] Schmehl M, Mussig J, Schoneld U, Von Buttlar HB. Life Cycle Assessment on a Bus Body Component Based on Hemp Fiber and PTP (R). J Polymer Environ. 2008;16:51-60.

[7] Wambua P, Ivens J, Verpoest I. Natural fibres: can they replace glass in fibre reinforced plastics? Compos Sci Technol. 2003;63:1259-64.

[8] Van de Weyenberg I, Truong TC, Vangrimde B, Verpoest I. Improving the properties of UD flax fibre reinforced composites by applying an alkaline fibre treatment. Comp Part A. 2006;37:1368-76. [9] Le Duigou A, Davies P, Baley C. Environmental Impact Analysis of the Production of Flax Fibres to be Used as Composite Material Reinforcement. J Biobased Mater Bio. 2011;5:153-65.

[10] Dissanayake NPJ, Summerscales J, Grove SM, Singh MM. Life Cycle Impact Assessment of Flax Fibre for the Reinforcement of Composites. J Biobased Mater Bio. 2009;3:245-8.

[11] Symington MC, Banks WM, West OD, Pethrick RA. Tensile Testing of Cellulose Based Natural Fibers for Structural Composite Applications. J Compos Mater. 2009;43:1083-108.

[12] Assarar M, Scida D, El Mahi A, Poilane C, Ayad R. Influence of water ageing on mechanical properties and damage events of two reinforced composite materials: Flax-fibres and glass-fibres. Mater Des. 2011;32:788-95.

[13] Bos HL, Molenveld K, Teunissen W, van Wingerde AM, van Delft DRV. Compressive behaviour of unidirectional flax fibre reinforced composites. J Mater Sci. 2004;39:2159-68.

[14] Osorio L, Trujillo E, Van Vuure AW, Verpoest I. Morphological aspects and mechanical properties of single bamboo fibers and flexural characterization of bamboo/epoxy composites. J Reinf Plast Compos. 2011;30:396-408.

[15] van Vuure A.W., Osorio L. , Trujillo E. , Fuentes C., Verpoest I. Long bamboo fibre composites. ICCM 18. Jeju2011.

[16] Ngoc TLQ. Polymer Composite Materials based on Coconut Fibres. Leuven: KU Leuven; 2012. [17] Torabizadeh MA. Tensile, compressive and shear properties of unidirectional glass/epoxy composites subjected to mechanical loading and low temperature services. Indian Journal of Engineering and Materials Sciences. 2013;20:299-309. 